\title{
Puna-apilasäilörehujen sulavuuden määrittäminen laboratoriomenetelmin
}

Kaisa Kuoppala ${ }^{1)}$, Marketta Rinne ${ }^{1)}$, Mikko Tuori ${ }^{2)}$, Pirjo Pursiainen ${ }^{2)}$ ja Aila Vanhatalo ${ }^{2)}$

${ }^{1)}$ MTT Kotieläintuotannon tutkimus, Eläinravitsemus, 31600 Jokioinen

${ }^{2)}$ Helsingin yliopisto, Kotieläintieteen laitos, PL 28, 00014 Helsingin yliopisto

\section{Tiivistelmä}

Nurmirehujen energia-arvo eli sulavuus vaihtelee huomattavasti. Tärkein sulavuuteen vaikuttava tekijä on kasvin kehitysvaihe korjuuhetkellä, mutta siihen vaikuttavat lisäksi mm. kasvilaji ja korjuutapa. Nurmirehujen sulavuuden luotettava arviointi on tärkeää taloudellisesti ja ravitsemuksellisesti järkevän karjanruokinnan suunnittelun pohjaksi. Korjuuaikatutkimukset on tehty pääasiassa nurmiheinäkasveilla, joista meillä yleisimmin ovat käytössä timotei ja nurminata. Sen sijaan puna-apilaa, joka Suomen olosuhteissa on nurmipalkokasveista tärkein säilörehukasvi, on tutkittu huomattavasti vähemmän. Puna-apilan kasvurytmi on erilainen kuin heinäkasvien ja se poikkeaa niistä myös kemialliselta koostumukseltaan.

Tässä tutkimuksessa arvioitiin nykyisin käytössä olevien analyysimenetelmien potentiaalia ennustaa puna-apilasäilörehun sulavuutta. Tarkoituksena oli selvittää kemiallisen koostumuksen (NDF, $\mathrm{ADF}$, raakavalkuainen, ligniini) ja entsymaattisten analyysien eli pepsiini-sellulaasiliukoisuuden (OMS) ja sulamattoman kuidun ( INDF) yhteyttä eläimillä määritettyyn orgaanisen aineen in vivo sulavuuteen (OMD) puna-apilan ensimmäisessä ja toisessa sadossa.

Tutkimusaineisto käsittää 19 puna-apilasäilörehua neljästä eri sulavuuskokeesta, jotka on tehty vuosina 2002-2004 HY:n Kotieläintieteen laitoksella ja MTT:n Eläinravitsemuksen tutkimusalalla. Säilörehujen orgaanisen aineen in vivo sulavuus (OMD) määritettiin ylläpitoruokintatasolla olevilla pässeillä tehdyissä sulavuuskokeissa sonnan kokonaiskeruumenetelmällä. Eri laboratoriomenetelmien soveltuvuutta OMD:n ennustamiseen tutkittiin lineaarisella regressioanalyysillä, jossa koepaikka oli satunnaistekijänä.

Parhaiten in vivo sulavuuden ennusti INDF (RMSE 12,1 g/kg ja $\mathrm{R}^{2}$ 0,959) ja toiseksi parhaiten sellulaasiliukoisuus (RMSE 12,9 g/kg ja $\mathrm{R}^{2}$ 0,951). Kemiallisten analyysien ennustevirheet olivat huomattavasti suuremmat ja selitysasteet pienemmät kuin INDF:n tai sellulaasiliukoisuuden. Puhtaasta puna-apilakasvustosta tehdyn säilörehun orgaanisen aineen in vivo sulavuus voidaan ennustaa yhtälöillä: OMD $(\mathrm{g} / \mathrm{kg})=837$ - 1,109 $\times$ INDF $(\mathrm{g} / \mathrm{kg} \mathrm{ka})$ tai OMD $(\mathrm{g} / \mathrm{kg})=100+0,821 \times \mathrm{OMS}(\mathrm{g} / \mathrm{kg})$.
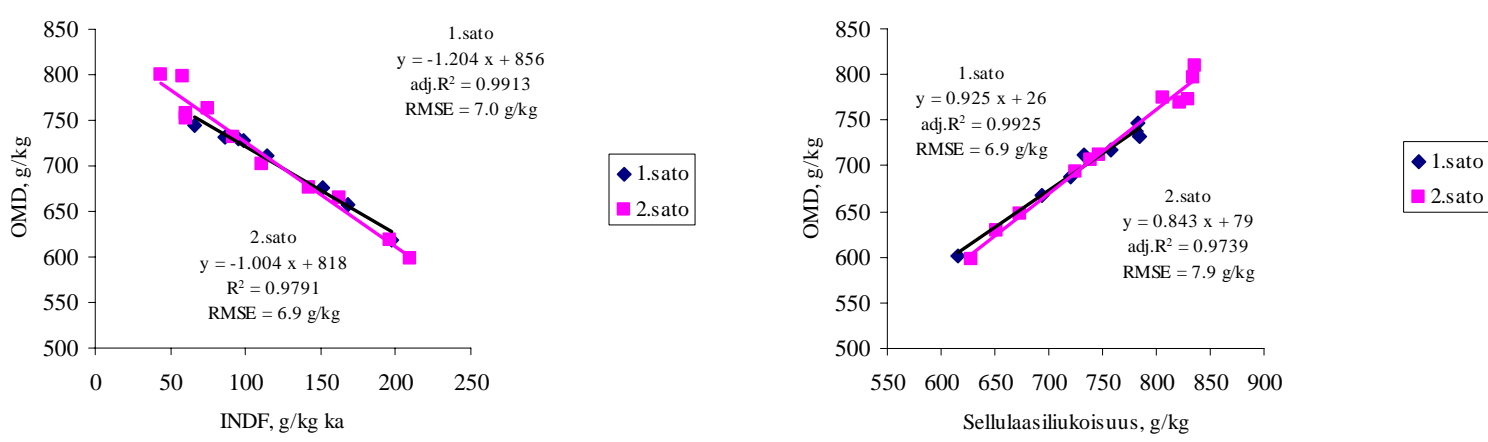

Sulamattoman kuidun (INDF) ja pepsiini-sellulaasiliukoisuuden yhteys puna-apilan orgaanisen aineen in vivo sulavuuteen (OMD) ensimmäisessä ja toisessa sadossa mixed regressiomallia käyttäen.

Asiasanat: säilörehu, puna-apila, sulavuus, sulamaton kuitu, pepsiini-sellulaasiliukoisuus 


\section{Johdanto}

Nurmirehujen energia-arvo eli sulavuus vaihtelee huomattavasti. Tärkein sulavuuteen vaikuttava tekijä on kasvin kehitysvaihe korjuuhetkellä, mutta siihen vaikuttavat lisäksi mm. kasvilaji ja korjuutapa. Nurmirehujen sulavuuden luotettava arviointi on tärkeää taloudellisesti ja ravitsemuksellisesti järkevän karjanruokinnan suunnittelun pohjaksi. Korjuuaikatutkimukset on tehty pääasiassa nurmiheinäkasveilla, joista meillä yleisimmin ovat käytössä timotei ja nurminata. Sen sijaan puna-apilaa, joka Suomen olosuhteissa on nurmipalkokasveista tärkein säilörehukasvi, on tutkittu huomattavasti vähemmän. Puna-apilan kasvurytmi on erilainen kuin heinäkasvien ja se poikkeaa heinäkasveista myös kemialliselta koostumukseltaan.

Tässä tutkimuksessa arvioitiin nykyisin käytössä olevien laboratorioanalyysimenetelmien potentiaalia ennustaa puna-apilasäilörehun sulavuutta. Tarkoituksena oli selvittää kemiallisten ja entsymaattisten analyysien kuten pepsiini-sellulaasiliukoisuuden ja sulamattoman kuidun (INDF) yhteyttä eläimillä määritettyyn orgaanisen aineen in vivo sulavuuteen puna-apilan ensimmäisessä ja toisessa sadossa. Tutkimus kuuluu MMM:n rahoittaman Luomututkimusohjelman projektiin ”Puna-apila tehokkaasti luomumaidoksi”.

\section{Aineisto ja menetelmät}

Tutkimusaineisto käsittää 19 puna-apilasäilörehua neljästä eri sulavuuskokeesta (taulukko 1). Alkuperäisestä aineistosta jouduttiin jättämään pois kaksi ensimmäisen sadon rehua ja yksi toisen sadon rehu kasvuston runsaan saunakukkapitoisuuden takia. Koepaikat ja -vuodet olivat: Siuntio v. 2002 (koe 1, Kuoppala ym. 2004), Jokioinen v. 2003 (koe 2), Vihti v. 2003 (koe 3) ja Helsinki v. 2004 (koe 4). Kokeissa oli käytössä kolme eri puna-apilalajiketta: Björn (koe 1), Jokioinen (kokeet 2 ja 3) sekä Varte (koe 4). Kaikki kasvustot olivat ensimmäisen satovuoden kasvustoja eikä niitä lannoitettu satovuonna. Säilörehut korjattiin eri kasvuvaiheissa sekä ensimmäisestä että toisesta sadosta. Kokeessa 1 säilörehut säilöttiin pyöröpaaleihin noin yhden vuorokauden esikuivatuksen jälkeen. Kokeessa 2 kasvusto niitettiin karholle, korjattiin tarkkuussilppurilla $\mathrm{n}$. 4 tunnin esikuivatuksen jälkeen ja säilöttiin $3 \mathrm{~m}^{3}: n$ koesiiloihin. Kokeessa 3 rehu korjattiin hienosilppurilla ja kuljetettiin Vihdistä välittömästi Viikkiin, jossa se säilöttiin $3 \mathrm{~m}^{3}$ :n koesiiloihin. Kokeessa 4 säilörehut pyöröpaalattiin noin yhden vuorokauden esikuivatuksen jälkeen. Rehut säilöttiin kaikissa koepaikoissa käyttäen säilöntäaineena AIV2Plusliuosta keskimäärin $5.8 \mathrm{l} / \mathrm{t}$.

Säilörehujen orgaanisen aineen in vivo sulavuus (OMD) määritettiin ylläpitoruokintatasolla olevilla pässeillä tehdyissä sulavuuskokeissa sonnan kokonaiskeruumenetelmällä MTT:n eläinravitsemuksella (kokeet 1 ja 2) ja HY:n Kotieläintieteen laitoksella (kokeet 3 ja 4). Kemialliset analyysit tehtiin joko MTT:n Eläinravitsemuksen tai HY:n Kotieläintieteen laitoksen laboratorioissa standardimenetelmin. Pepsiini-sellulaasiliukoisuus (OMS) tehtiin joko Valiolla Nousiaisen ym. (2003a) menetelmällä tai MTT:llä sen modifikaatiolla käyttäen Trichoderma viriden (Onozuka R-10, Yakulta Pharmaceutical Ltd, Japani) sellulaasientsyymiä. INDF-pitoisuus määritettiin MTT:ssä 12 vuorokauden nailonpussi-inkubaatiolla (pussien huokoskoko $17 \mu \mathrm{m}$ ) Ahvenjärven ym. (2001) mukaan.

Laboratoriomenetelmien ja orgaanisen aineen in vivo sulavuuden välistä yhteyttä tutkittiin lineaarisella regressioanalyysillä. Mixed-malli analysoitiin SAS:n MIXED-proseduurilla niin, että koepaikka oli mallissa mukana satunnaistekijänä: $Y_{i j k}=A_{0}+$ Paikka $_{i}+B_{1} X_{i j}+e_{i j k}$, missä $A_{0}$ on vakio (kiinteä tekijä), Paikka $a_{\mathrm{i}}$ on koepaikan satunnaisvaikutus, $\mathrm{B}_{1}$ on regressiokerroin ja $\mathrm{e}_{\mathrm{ijk}}$ on virhetermi. Vertailu tehtiin käyttämällä mallin selitysastetta $\left(\right.$ Adj. $R^{2}$ ) ja virhetermiä (Residual Mean Square Error, RMSE). Koepaikka sisältää kokeiden välisen vaihtelun (yhdellä paikkakunnalla tehdyt säilörehut tutkittiin samassa kokeessa ja näytteet analysoitiin samalla kertaa samoissa laboratorioissa) lisäksi eri paikkakuntien erilaiset sääolot.

\section{Tulokset ja tulosten tarkastelu}

Säilörehujen kemiallinen koostumus ja sulavuus vaihtelivat odotetusti paljon (taulukko 1). INDF:n ja ligniinin osuus NDF:stä oli aineistossa keskimäärin 328 ja 120 g/kg. Ne ovat selvästi korkeammat kuin heinäkasveilla. Nousiaisen ym. (2004) heinäkasvisäilörehujen aineistossa vastaavat luvut olivat 157 ja 53. INDF:n osuus NDF:stä oli Kuoppalan ym. (2006) kokeessa puna-apilalla ja heinäkasveilla keskimäärin 243 ja 131 g/kg, Oltin ym. (2005) palkokasviaineistossa 328 g/kg ja Pursiaisen ym. (2006) puna-apilakokeen säilörehuissa $466 \mathrm{~g} / \mathrm{kg}$. 
Taulukko 1. Tutkimusaineiston säilörehujen korjuupäivämäärät, kemiallinen koostumus, pepsiinisellulaasiliukoisuus (OMS) ja orgaanisen aineen in vivo sulavuus (OMD).

\begin{tabular}{|c|c|c|c|c|c|c|c|c|c|c|c|c|c|c|}
\hline \multirow[b]{2}{*}{$\begin{array}{l}\text { Koe- } \\
\text { paikka }\end{array}$} & \multirow[b]{2}{*}{ Vuosi } & \multirow[b]{2}{*}{$\begin{array}{l}\text { Korj. } \\
\text { pvm }\end{array}$} & \multirow[b]{2}{*}{$\begin{array}{l}\text { Edell. } \\
\text { korj. } \\
\text { pvm }\end{array}$} & \multirow[b]{2}{*}{$\begin{array}{r}\text { Sa- } \\
\text { to }\end{array}$} & \multirow[b]{2}{*}{$\begin{array}{l}\text { Kuiva- } \\
\text { aine, } \\
\text { g/kg }\end{array}$} & \multicolumn{7}{|c|}{ g/kg kuiva-ainetta } & \multicolumn{2}{|c|}{$\mathrm{g} / \mathrm{kg}$} \\
\hline & & & & & & $\begin{array}{l}\text { Tuh- } \\
\text { ka }\end{array}$ & $\mathrm{RV}$ & NDF & $\mathrm{ADF}$ & $\begin{array}{l}\text { Lig- } \\
\text { niini }\end{array}$ & $\mathrm{ADL}$ & INDF & OMS & $\begin{array}{c}\text { In } \\
\text { vivo } \\
\text { OMD } \\
\end{array}$ \\
\hline \multicolumn{15}{|c|}{$\begin{array}{llll} & \\
\end{array}$} \\
\hline Siuntio & 2002 & 7.6. & & 1 & 332 & 120 & 220 & 286 & 196 & 30 & & 58 & 836 & 790 \\
\hline Siuntio & 2002 & 19.6. & & 1 & 224 & 111 & 190 & 346 & 236 & 38 & & 99 & 782 & 719 \\
\hline Siuntio & 2002 & 10.7 . & & 1 & 232 & 99 & 146 & 482 & 343 & 76 & & 196 & 652 & 610 \\
\hline Siuntio & 2002 & 2.8. & 7.6. & 2 & 209 & 104 & 156 & 486 & 354 & 79 & & 210 & 628 & 581 \\
\hline Siuntio & 2002 & 2.8. & 19.6. & 2 & 202 & 116 & 188 & 399 & 270 & 49 & & 114 & 733 & 695 \\
\hline Siuntio & 2002 & 15.8. & 10.7 . & 2 & 414 & 122 & 183 & 338 & 230 & 42 & & 87 & 785 & 715 \\
\hline \multicolumn{15}{|l|}{ Koe 2.} \\
\hline Jokioinen & 2003 & 2.7. & & 1 & 191 & 103 & 200 & 344 & 241 & 33 & & 75 & 806 & 758 \\
\hline Jokioinen & 2003 & 16.7. & & 1 & 187 & 92 & 168 & 448 & 323 & 58 & & 152 & 720 & 672 \\
\hline Jokioinen & 2003 & 12.8. & 2.7 & 2 & 269 & 111 & 206 & 325 & 206 & 39 & & 95 & 783 & 746 \\
\hline Jokioinen & 2003 & 26.8 . & 2.7 & 2 & 229 & 92 & 192 & 369 & 253 & 57 & & 143 & 725 & 692 \\
\hline Jokioinen & 2003 & 26.8. & 16.7. & 2 & 211 & 98 & 256 & 276 & 181 & 20 & & 60 & 830 & 772 \\
\hline Jokioinen & 2003 & 9.9. & 16.7. & 2 & 238 & 100 & 238 & 274 & 174 & 21 & & 60 & 822 & 768 \\
\hline \multicolumn{15}{|l|}{ Koe 3.} \\
\hline Vihti & 2003 & 17.6. & & 1 & 211 & 91 & 198 & 254 & 146 & 24 & 11 & 44 & 834 & 777 \\
\hline Vihti & 2003 & 22.8. & 1.7. & 2 & 249 & 84 & 202 & 300 & 156 & 36 & 19 & 92 & 739 & 710 \\
\hline Vihti & 2003 & 9.9. & 14.7. & 2 & 256 & 95 & 230 & 259 & 133 & 22 & 15 & 66 & 758 & 722 \\
\hline \multicolumn{15}{|l|}{ Koe 4.} \\
\hline Helsinki & 2004 & 2.7 . & & 1 & 183 & 81 & 160 & 400 & 277 & & 34 & 163 & 674 & 700 \\
\hline Helsinki & 2004 & 16.7. & & 1 & 224 & 90 & 158 & 387 & 281 & & 39 & 197 & 616 & 655 \\
\hline Helsinki & 2004 & 25.8. & 2.7 . & 2 & 242 & 89 & 168 & 373 & 258 & & 32 & 168 & 693 & 680 \\
\hline Helsinki & 2004 & 25.8. & 16.7. & 2 & 193 & 102 & 194 & 322 & 223 & & 21 & 111 & 747 & 725 \\
\hline$n$ & & & & & 19 & 19 & 19 & 19 & 19 & 15 & 7 & 19 & 19 & 19 \\
\hline Keskiarvo & & & & & 237 & 100 & 192 & 351 & 236 & 42 & 24 & 115 & 746 & 710 \\
\hline SD & & & & & 55,4 & 11,7 & 29,6 & 70,6 & 63,8 & 19,3 & 10,6 & 52,6 & 69,0 & 55,2 \\
\hline Minimi & & & & & 183 & 81 & 146 & 254 & 133 & 20 & 11 & 44 & 616 & 581 \\
\hline Maksimi & & & & & 414 & 122 & 256 & 486 & 354 & 79 & 39 & 210 & 836 & 790 \\
\hline
\end{tabular}

Säilörehujen NDF-, ADF ja INDF-pitoisuudet olivat negatiivisessa ja raakavalkuainen ja sellulaasiliukoisuus positiivisessa yhteydessä orgaanisen aineen in vivo sulavuuteen (taulukko 2). Parhaiten in vivo sulavuuden ennusti INDF ja toiseksi parhaiten sellulaasiliukoisuus. Tulos on yhdenmukainen Nousiaisen ym. (2003b) heinäkasvisäilörehuaineiston tulosten kanssa, jossa INDF ennusti parhaiten orgaanisen aineen in vivo sulavuuden. Sen sijaan Rinteen ym. (2005) palkokasviaineistossa, joka sisälsi osittain samojen puna-apilasäilörehujen lisäksi myös ulkomaisia puna-apila- ja sinimailassäilörehuja sekä vuohenhernesäilörehuja, oli sellulaasiliukoisuus parempi sulavuuden ennustaja kuin INDFpitoisuus.

Taulukko 2. Puna-apilasäilörehujen orgaanisen aineen in vivo sulavuuden ennustaminen eri laboratoriomenetelmillä ( $n=19)$.

\begin{tabular}{lcrrrrrrr}
\hline Muuttuja & Vakio A & \multicolumn{1}{c}{ S.E. } & P-arvo & kerroin B & \multicolumn{1}{c}{ S.E. } & P-arvo & RMSE & Adj.R ${ }^{2}$ \\
\hline Raakavalkuainen & 419 & 51,7 & $<0,0001$ & 1,510 & 0,2662 & $<0,0001$ & 33,9 & 0,634 \\
NDF & 969 & 24,9 & $<0,0001$ & $-0,747$ & 0,0696 & $<0,0001$ & 20,8 & 0,864 \\
ADF & 913 & 20,8 & $<0,0001$ & $-0,885$ & 0,0851 & $<0,0001$ & 23,0 & 0,856 \\
Ligniini (n=15) & 839 & 13,1 & $<0,0001$ & $-3,032$ & 0,2892 & $<0,0001$ & 20,4 & 0,886 \\
INDF & 837 & 6,8 & $<0,0001$ & $-1,109$ & 0,0543 & $<0,0001$ & 12,1 & 0,959 \\
OMS $^{1)}$ & 100 & 32,9 & 0,0074 & 0,821 & 0,0439 & $<0,0001$ & 12,9 & 0,951 \\
\hline
\end{tabular}

1) OMS = orgaanisen aineen pepsiini-sellulaasiliukoisuus 
Kun ensimmäinen ja toinen sato analysoitiin erikseen, mallien selitysasteet paranivat (taulukko 3, kuvat 1 ja 2). Ensimmäisen sadon selitysaste oli INDF:llä parempi verrattuna toiseen satoon, mutta sellulaasiliukoisuudella toisen sadon selitysaste oli hieman parempi. Satojen välinen ero ei liene käytännössä merkittävä, joten ennustekaavana voidaan käyttää molemmille sadoille samaa yhtälöä.

Kemialliset parametrit ennustivat selvästi huonommin sulavuuden muutoksia kuin INDF tai OMS tässä kokeessa samoin kuin Nousiaisen ym. (2003b) heinäkasviaineistossa. Edes kahta kemiallista analyysiä käyttäen mallin luotettavuus ei parantunut (taulukko 4.) Ligniinipitoisuuden lisääminen INDF:n tai OMS:n lisäksi malliin paransi mallin selitysastetta ja pienensi virhettä, mutta muutos oli OMS:n kanssa pieni. Heinäkasveilla ligniinipitoisuuden lisääminen vastaavanlaiseen malliin OMS:n lisäksi ei parantanut selitysastetta tai pienentänyt virhettä (Nousiainen ym. (2003b.

Taulukko 3. Puna-apilasäilörehujen orgaanisen aineen in vivo sulavuuden ennustaminen INDF pitoisuudesta tai pepsiini-sellulaasiliukoisuudesta käyttäen mixed regressioanalyysiä ( $\mathrm{n}=19)$ ensimmäisessä ja toisessa sadossa erikseen.

\begin{tabular}{|c|c|c|c|c|c|c|c|c|}
\hline Muuttuja & Vakio A & S.E. & P-arvo & kerroin B & S.E. & P-arvo & RMSE & Adj. R $^{2}$ \\
\hline \multicolumn{9}{|l|}{ INDF } \\
\hline 1.sato & 856 & 5,8 & $<0,0001$ & $-1,204$ & 0,0427 & $<0,0001$ & 6,96 & 0,991 \\
\hline 2.sato & 818 & 5,5 & $<0,0001$ & $-1,004$ & 0,0464 & $<0,0001$ & 6,93 & 0,980 \\
\hline \multicolumn{9}{|l|}{ OMS } \\
\hline 1.sato & 26 & 22,6 & 0,3005 & 0,925 & 0,0303 & $<0,0001$ & 6,92 & 0,993 \\
\hline 2.sato & 79 & 32,7 & 0,0385 & 0,843 & 0,0436 & $<0,0001$ & 7,94 & 0,974 \\
\hline
\end{tabular}

\section{Johtopäätökset}

Sulamaton kuitu ennusti parhaiten puna-apilasäilörehujen orgaanisen aineen in vivo sulavuuden ja pepsiini-sellulaasiliukoisuus toiseksi parhaiten. Puhtaasta puna-apilakasvustosta tehdyn säilörehun orgaanisen aineen in vivo sulavuus voidaan ennustaa yhtälöillä: OMD $(\mathrm{g} / \mathrm{kg})=837-1,109 \times$ INDF $(\mathrm{g} / \mathrm{kg} \mathrm{ka})$ tai OMD $(\mathrm{g} / \mathrm{kg})=100+0,821 \times \mathrm{OMS}(\mathrm{g} / \mathrm{kg})$. Kemiallisia analyysejä kuten NDF, ADF, raakavalkuainen tai ligniini ei voida pitää luotettavina sulavuuden kuvaajina.

\section{Kirjallisuus}

Ahvenjärvi, S., Skiba, B., Huhtanen, P. 2001. Effect of heterogeneous digesta chemical composition on the accuracy of measurements of fiber flow in dairy cows. Journal of Animal Science 79: 1611-1620.

Kuoppala, K., Ahvenjärvi, S., Rinne, M. ja Vanhatalo, A. 2006. Puna-apilasäilörehun solunseinäkuitu on erilaista kuin timotei-nurminatasäilörehun. Maataloustieteen Päivät 2006.

Nousiainen, J., Rinne, M., Hellämäki, M., Huhtanen, P. 2003a. Prediction of the digestibility of the primary growth of grass silages harvested at different stages of maturity from chemical composition and pepsin-cellulase solubility. Animal Feed Science and Technology 103, 1-4: 97-111.

Nousiainen, J., Rinne, M., Hellämäki, M., Huhtanen, P. 2003b. Prediction of the digestibility of primary growth and regrowth grass silages from chemical composition, pepsin-cellulase solubility and indigestible cell wall content. Animal Feed Science and Technology 110, 1-4: 61-74.

Nousiainen, J., Ahvenjärvi, S., Rinne, M., Hellämäki, M., Huhtanen, P. 2004. Prediction of indigestible cell wall fraction of grass silage by near infrared reflectance spectroscopy. Animal Feed Science and Technology 115, 3-4: 295-311.

Rinne, M., Olt, A., Nousiainen, J., Seppälä, A., Tuori, M., Paul, C., Fraser, M.D., Huhtanen, P. 2005. Prediction of legume silage digestibility from various laboratory methods. Grass and Forage Science, submitted.

Pursiainen, P., Tuori, M., Kuoppala, K., Rinne, M., Huhtanen, P. ja Vanhatalo, A. 2006. Punaapilasäilörehun korjuuajan vaikutus maidontuotantoon. Maataloustieteen Päivät 2006. 
SUOMEN MAATALOUSTIETEELLISEN SEURAN TIEDOTE NRO 21

Taulukko 4. Puna-apilasäilörehujen orgaanisen aineen in vivo sulavuuden ennustaminen eri laboratoriomenetelmillä kahden tekijän regressiomallilla ( $\mathrm{n}=19$ ).

\begin{tabular}{|c|c|c|c|c|c|c|c|c|c|c|c|}
\hline Muuttujat & Vakio A & S.E. & P-arvo & kerroin $\mathrm{B}$ & S.E. & P-arvo & kerroin $\mathrm{C}$ & S.E. & P-arvo & RMSE & Adj. $R^{2}$ \\
\hline NDF, ADF & 1023 & 40,0 & $<0,0001$ & $-1,528$ & 0,365 & 0,0007 & 0,940 & 0,404 & 0,337 & 21,7 & 0,841 \\
\hline NDF, Ligniini & 886 & 46,6 & $<0,0001$ & $-0,247$ & 0,247 & 0,3365 & $-2,135$ & 1,015 & 0,057 & 19,5 & 0,900 \\
\hline ADF, Ligniini & 816 & 24,9 & $<0,0001$ & 0,247 & 0,231 & 0,3052 & $-3,793$ & 0,854 & 0,001 & 22,9 & 0,854 \\
\hline NDF, RV & 1057 & 101,1 & $<0,0001$ & $-0,857$ & 0,130 & $<0,0001$ & $-0,267$ & 0,309 & 0,401 & 20,4 & 0,873 \\
\hline INDF, NDF & 855 & 21,2 & $<0,0001$ & $-0,993$ & 0,126 & $<0,0001$ & $-0,090$ & 0,094 & 0,351 & 12,5 & 0,956 \\
\hline INDF, ADF & 838 & 13,0 & $<0,0001$ & $-1,102$ & 0,116 & $<0,0001$ & $-0,007$ & 0,096 & 0,942 & 12,5 & 0,956 \\
\hline INDF, Ligniini & 829 & 5,6 & $<0,0001$ & $-2,15$ & 0,221 & $<0,0001$ & 2,514 & 0,594 & 0,001 & 8,4 & 0,983 \\
\hline INDF, RV & 919 & 47,5 & $<0,0001$ & $-1,272$ & 0,106 & $<0,0001$ & $-0,330$ & 0,189 & 0,101 & 12,1 & 0,959 \\
\hline OMS, NDF & 344 & 74,2 & 0,0003 & 0,603 & 0,071 & $<0,0001$ & $-0,236$ & 0,070 & 0,004 & 12,3 & 0,953 \\
\hline OMS, ADF & 266 & 60,2 & 0,0004 & 0,665 & 0,063 & $<0,0001$ & $-0,219$ & 0,068 & 0,006 & 12,2 & 0,956 \\
\hline OMS, Ligniini & 150 & 95,6 & 0,1419 & 0,771 & 0,107 & $<0,0001$ & $-0,559$ & 0,361 & 0,148 & 10,4 & 0,970 \\
\hline OMS, RV & 109 & 35,4 & 0,0074 & 0,763 & 0,078 & $<0,0001$ & 0,182 & 0,181 & 0,331 & 12,9 & 0,951 \\
\hline INDF, OMS & 492 & 125,5 & 0,0012 & $-0,603$ & 0,185 & 0,0048 & 0,386 & 0,141 & 0,014 & 11,6 & 0,961 \\
\hline
\end{tabular}

1) OMS = orgaanisen aineen pepsiini-sellulaasiliukoisuus 

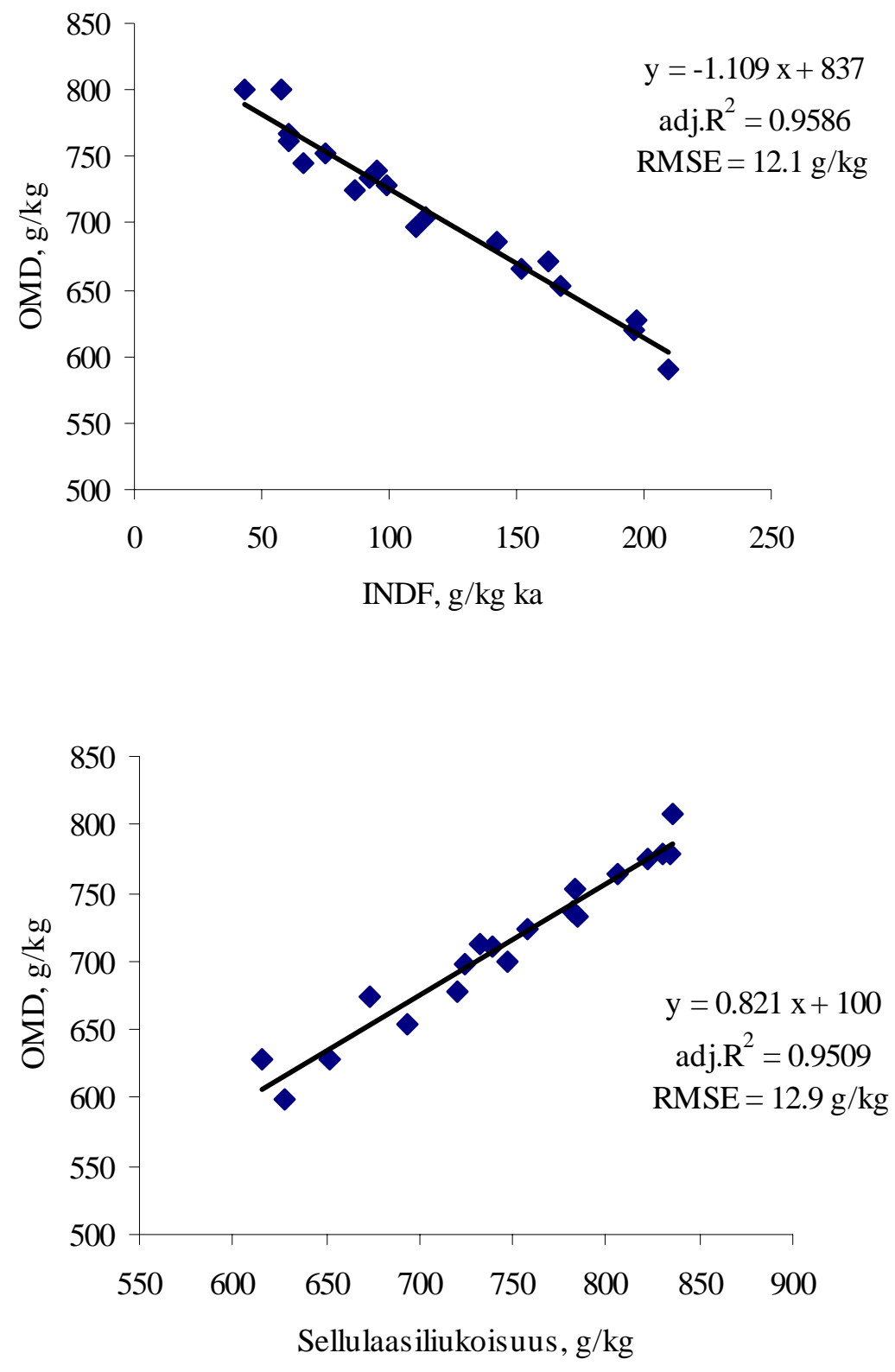

Kuva 1. Sulamattoman kuidun (INDF) ja pepsiini-sellulaasiliukoisuuden yhteydet orgaanisen aineen in vivo sulavuuteen (OMD) mixed regressiomallia käyttäen. 

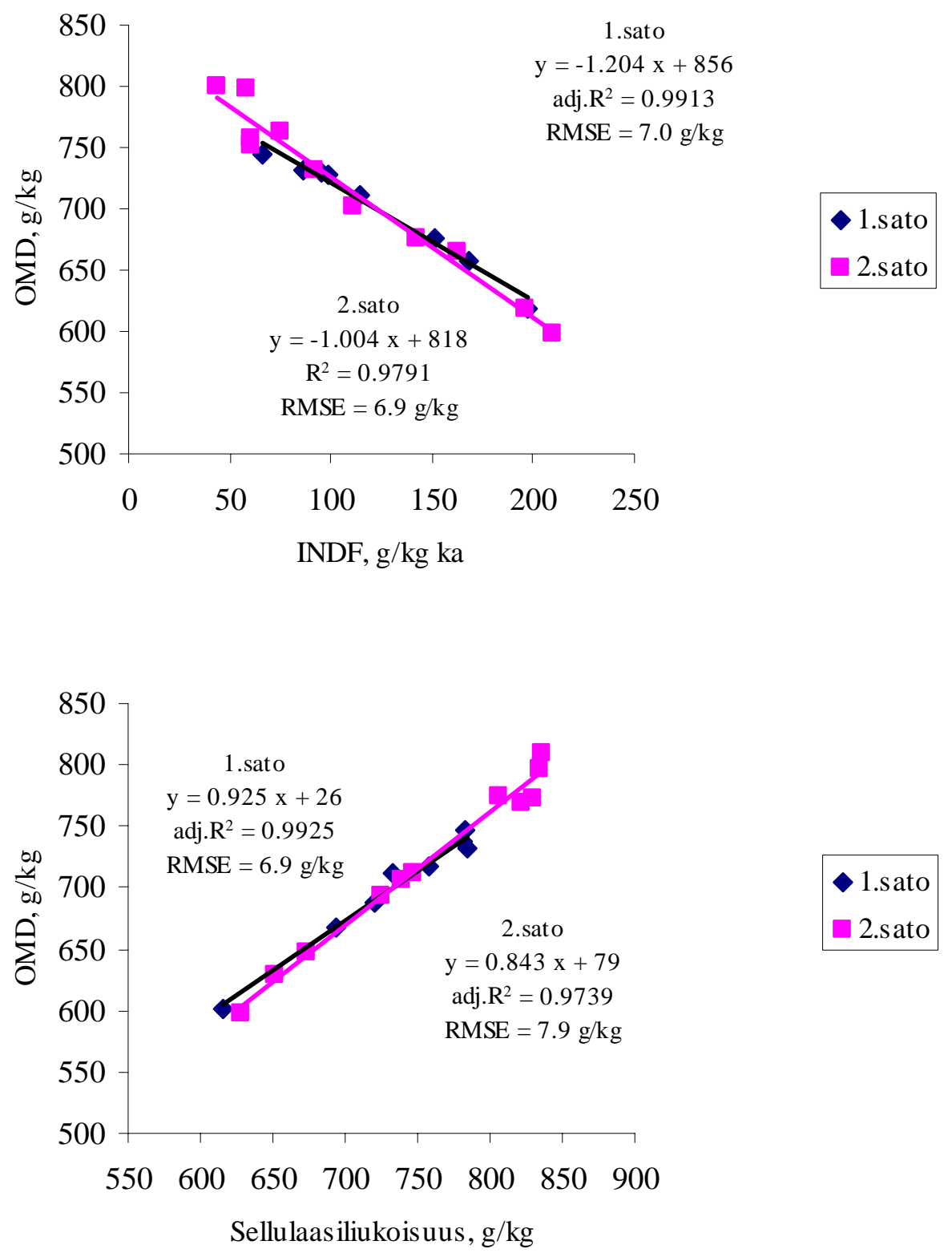

Kuva 2.Sulamattoman kuidun (INDF) ja pepsiini-sellulaasiliukoisuuden yhteydet orgaanisen aineen in vivo sulavuuteen (OMD) ensimmäisessä ja toisessa sadossa mixed regressiomallia käyttäen. 